İşletme Ekonomi ve Yönetim Araştırmaları Dergisi

(The Journal of Business, Economic and Management Research)

Y1l 2021 / Say1: 2 / 277 - 293

Araștırma Makalesi

Gönderilme Tarihi: 7 Nisan 2021; Revize Edilmiş Hali: 16 Mayıs 2021; Kabul Tarihi: 17 Mayıs 2021

\title{
INVESTIGATING THE RELATIONSHIP BETWEEN STUDENT SATISFACTION \\ CRITERIA: A HYBRID MODEL BASED ON DEMATEL AND CANONICAL CORRELATION ANALYSIS
}

\author{
Seda ABACIOĞLU $\mathbf{U}^{12}$
}

Büşra AYAN ${ }^{3}$

\begin{abstract}
This study aims to investigate the relationship between students' satisfaction criteria with a hybrid model, conducting both DEMATEL and Canonical Correlation Analysis. The dataset is obtained from Turkey University Satisfaction Survey (TUSS) 2020, consisting of a total of 192 universities and 39,386 students. TUSS has six factors, namely, "campus and the fulfilment of campus life", "academic support and interest", "richness of learning opportunities and resources", "personal development and career support", "satisfaction with the learning experience", and "satisfaction with the institution's management and operation". DEMATEL is conducted to understand the cause and effect relationship and group these factors into two categories as dependent and independent sets. To investigate the relationship between these sets more deeply, Canonical Correlation Analysis is (CCA) carried out. The results of CCA are interpreted through canonical weights, canonical loadings, canonical cross-loadings, the proportion of explained variance, and redundancy index. The findings of the study suggest that to increase the overall satisfaction towards the institution, academic support and interest, as well as personal development and career support, should be delved into very carefully.
\end{abstract}

Keywords: Student Satisfaction, Turkey University Satisfaction Survey, DEMATEL, Canonical Correlation Analysis.

JEL Codes: M19, C30, C44, I23.

\section{ÖĞRENCİ MEMNUNIYETI KRITTERLERİ ARASINDAKİ İLIŞKININ İNCELENMESİ: DEMATEL VE KANONIK KORELASYON ANALİİ TEMELLİ BIR HIBBITT MODEL}

Öz

Bu çalışma, çok kriterli karar verme (MCDM) tekniği ve çok değişkenli istatistiksel teknik ile özgün bir yaklaşım sunan hibrit bir model aracılığıla, öğrenci memnuniyeti kriterleri arasındaki ilişkiyi araştırmayı amaçlamaktadır. Veri seti, 192 üniversite ve 39.386 öğrenciden oluşan Türkiye Üniversite Memnuniyet Anketi (TÜMA) 2020'den alınmıştır. TÜMA’nın altı faktörü vardır; "yerleşke ve yerleşke yaşamının doyuruculuğu", “akademik destek ve ilgi”, "öğrenme imkan ve kaynaklarının zenginliği”, "kişisel gelişim ve kariyer desteği”, "öğrenim deneyiminin tatminkârlı̆̆ı" ve "kurumun yönetim ve işleyişinden memnuniyet". DEMATEL, neden sonuç ilişkisini anlamak ve bu faktörleri bağımlı ve bağımsız kümeler olarak iki kategoriye ayırmak için uygulanmıştır. Bu gruplar arasındaki ilişkiyi daha derinlemesine incelemek için Kanonik Korelasyon Analizi (KKA) gerçekleştirilmiştir. KKA sonuçları, kanonik ağılıklar, kanonik yükler, kanonik çapraz yükler, açıklanan varyans oranı ve gereksizlik indeksi ile yorumlanmıştır. Bu çalışmanın bulguları, kuruma yönelik genel

\footnotetext{
${ }^{1}$ Doktora Programı Öğrencisi, İstanbul Üniversitesi, Sosyal Bilimler Enstitüsü, Sayısal Yöntemler Anabilim Dalı

2 Arş. Gör., Ondokuz Mayıs Üniversitesi, İktisadi ve İdari Bilimler Fakültesi, İșletme Bölümü, ORCID-ID:0000-0002-3150-2770, seda.abacioglu@omu.edu.tr

3 Arş. Gör., MEF Üniversitesi, İktisadi, İdari ve Sosyal Bilimler Fakültesi, İşletme Bölümü, ORCID-ID:0000-0002-5212-2144, ayanbu@mef.edu.tr
} 
memnuniyetin artırılması için akademik destek ve ilginin yanı sıra kişisel gelişim ve kariyer desteğinin çok dikkatli bir şekilde araştırılması gerektiğini göstermektedir.

Anahtar Kelimeler: Öğrenci Memnuniyeti, Türkiye Üniversite Memnuniyet Araştırması, DEMATEL, Kanonik Korelasyon Analizi.

JEL Kodları: M19, C30, C44, I23.

\section{INTRODUCTION}

"Students, so long taken for granted, have been recognized as the principal stakeholders in higher education and their own voice on their experiences is now being heard more clearly by institutions and governments."

Williams \& Cappuccini-Ansfield (2007, p.159)

In parallel to several studies that show the important impact of student satisfaction on different outcomes such as student motivation and retention, higher education institutions delve into student satisfaction as to include contents in mission statements, goals, and promotional activities (Elliott \& Shin, 2002). The crucial role of the students in assessing institutions is undeniable. Their opinions are extremely important and should be taken into consideration very carefully (Harvey, 1995).

There is a growing interest in developing student feedback mechanisms in higher education institutions (Williams \& Cappuccini-Ansfield, 2007). Due to the complex structure of higher education institutions from academic staff to management, higher education assessment has conflicts such as determining the level of student satisfaction and students' perception of the education quality (Zineldin et al., 2011). Measuring satisfaction can be assessed with a single-item or multi-item rating scale (Elliott \& Shin, 2002).

Studies focusing on student satisfaction are carried out on a local, national, or worldwide based. Douglas et al. (2006) measure student satisfaction at a university in the United Kingdom. The result of the study states that teaching and learning aspects are the most important, whereas the physical facilities aspects are the least important. Butt \& Rehman (2010) investigate student satisfaction at public and private universities in Pakistan. Similarly, classroom facilities are found to be the least important, while academic expertise is found to be the most influential factor. There are numerous studies on student satisfaction in Turkey. Tütüncü \& İpekgil Doğan (2003) investigate the satisfaction levels of students at Dokuz Eylül University. In the study, quality of education is found to be the most influential variable and the most important factors among the determinants of education quality are the quality of the academic staff and the course structures, respectively. Naralan \& Kaleli (2012) measure the expectations and satisfaction levels of undergraduate students at Atatürk University. As a result of the study, suggestions are made in line with the students' campus-related expectations such as improving social and cultural activities on the campus, tightening the security, and making internet access easier. Tayyar \& Dilşeker (2012) investigate the relationship between service quality, image, student satisfaction, recommendation and loyalty among universities. In this context, student satisfaction is found to be 
influential on loyalty and recommendation. To increase student satisfaction, focusing on activities that improve academic staff, internationalization and image are suggested.

In another study, the lecture room facilities, library facilities, accommodation facilities, employment facilities and entertainment facilities are found to be the factors affecting student overall satisfaction (Weerasinghe \& Fernando, 2018). Similarly, Hanssen \& Solvoll (2015) explore facilities that influence overall student satisfaction and find out that social areas, auditoriums and libraries are the most important. Kärnä \& Julin (2015) find that factors related to the research and teaching aspects have the greatest impacts on overall satisfaction. Solinas et al. (2012) investigate factors affecting student satisfaction under three categories; motivations of students, services provided by universities and teaching capabilities. Wiers-Jenssen et al. (2002) emphasize the importance of academic quality among the factors that determine student satisfaction. In addition to that, they suggest that the social environment, physical infrastructure, and service quality of administrative staff are important. Elliott (2002) states that students' sense of belonging and provision of a high-quality education are the main factors in determining student satisfaction.

Students satisfaction criteria may change in different circumstances. Bolliger (2004) states the key factors of student satisfaction in online courses, which are instructor variables, technical issues, and interactivity. Other than evaluating the overall student satisfaction, some studies measure student satisfaction of a certain degree (e.g. PhD student satisfaction (Barnes \& Randall, 2012; Dericks et al., 2019)) or a specific department such as business administration (Gibson, 2010; Letcher \& Neves, 2010), informatics (Koilias, 2005), psychology (Green et al., 2015), and engineering (González-Rogado et al., 2014). Besides, some studies look at the aspects that have impacts on student satisfaction. The effects of academic departments (Umbach \& Porter, 2002), classroom attributes (Yang et al., 2013), service quality and price fairness (Tuan, 2012), and academic environment and background characteristics (Karemera et al., 2003) on student satisfaction are examined.

Student satisfaction surveys, part of the quality assurance framework, have been used to improve overall satisfaction in universities by evaluating areas in need of improvement and rewarding areas of excellence (Grebennikov \& Shah, 2013). Due to several opportunities that student satisfaction provides, institutions delve into satisfaction criteria more deeply. This study focuses on student satisfaction criteria from a different angle to investigate the relationship between satisfaction aspects. The rest of this study is structured as follows. The next session provides an overview of the Turkey University Satisfaction Survey. The methodology session gives dataset information and explains the analysis techniques, DEMATEL and Canonical Correlation Analysis. Finally, the findings of the analysis are given and the results are discussed.

\section{TURKEY UNIVERSITY SATISFACTION SURVEY}

University rankings according to various criteria have been carried out since the beginning of the 20th century. Turkey University Satisfaction Survey (TUSS), the most comprehensive university satisfaction survey conducted in Turkey, tries to draw attention to the processes and inputs of university 
life such as education, campus life, management, and access to opportunities, which can be seen as important aspects of the university ecology. TUSS was first carried out in 2016 by the founders of the University Research Laboratory, Karadağ and Yücel (Karadağ \& Yücel, 2017).

TUSS has created a university ranking based on student satisfaction and sought answers to the following questions (Karadağ \& Yücel, 2017):

- Do universities in Turkey satisfy their students in the terms of their learning experience?

- Do universities present the space and human relationship at a satisfactory level by creating a fulfilling and attractive campus life?

- Going beyond attendance and covering subjects, do universities give academic support for students and attention to the academic difficulties their students face?

- Can the demands of the students be met quickly at a satisfactory level in terms of the administration and operation of the university?

- Are the universities' learning environment, opportunities, and resources rich and sufficient?

- Can students' personal development and future careers be supported?

Seeking this information, TUSS gives comprehensive knowledge for students' satisfaction towards universities in terms of different aspects such as learning experience, campus life, academic support, management, opportunities, and personal development. Since 2016, the report, which is prepared based on the sample participants' results collected from universities, is published on the website (Uniar, 2021). The sample was determined in five stages for the latest published report, TUSS2020 (Karadağ \& Yücel, 2020):

- Stage 1: Based on the statistics of the Council of Higher Education (YÖK) in 2019-2020 academic year, a total of 192 state and foundation universities were determined (state:125, foundations:67).

- Stage 2: Taking into account the distribution of the total number of students in universities by faculty types and gender, the sample size to be reached for each faculty type (in terms of gender) was calculated.

- Stage 3: Universities were divided into 10 main and 5 sub-categories according to their undergraduate student size, and the minimum sample size to be reached for each university was calculated.

- Stage 4: The minimum sample size to be reached for the faculties of each university was calculated by considering the faculty and gender ratios within each university.

- Stage 5: Using quota sampling, data were collected from at least 75 students from each university students (the number varies depending on the size of the university) by using dynamic software Application with questionnaires applied from 1 March and 30 April.

The data are collected with the Student Satisfaction Scale consisting of six factors. The ranking is made by calculating the General Satisfaction Score with a maximum of 600 and a minimum of 60 by 
adding the scores of each university in six fields. Universities are classified in the 6-point range. Levels are named A+, A, B, C, D, and FF (Karadağ \& Yücel, 2020). The factors and their explanations are given in Table 1.

Table 1. Contents of the Student Satisfaction Scale

\begin{tabular}{|c|c|}
\hline Factor & Content \\
\hline $\begin{array}{l}\text { Satisfaction with Learning } \\
\text { Experience }\end{array}$ & $\begin{array}{l}\text { Satisfaction with the courses and their contents, the interest } \\
\text { of the instructors, the validity of the exams, the student- } \\
\text { oriented climate, the teaching methods and approaches in } \\
\text { the classroom }\end{array}$ \\
\hline $\begin{array}{l}\text { Campus and the Fulfilment of } \\
\text { Campus Life }\end{array}$ & $\begin{array}{l}\text { The attractiveness of the campus environment, social } \\
\text { facilities, dormitory's facilities and quality, ease of } \\
\text { transportation, security, aesthetics and usability of the } \\
\text { physical spaces, the environment where the campus is } \\
\text { located }\end{array}$ \\
\hline Academic Support and Interest & $\begin{array}{l}\text { Accessibility to lecturers and counsellors, finding help in } \\
\text { learning difficulties, sensitivity to students academic } \\
\text { questions and their problems. }\end{array}$ \\
\hline $\begin{array}{l}\text { Satisfaction with the Institution's } \\
\text { Management and Operation }\end{array}$ & $\begin{array}{l}\text { Student affairs, exam schedules, academic calendar, } \\
\text { codetermination, access to administrators, effectiveness, } \\
\text { and sensitivity of the administrative function }\end{array}$ \\
\hline $\begin{array}{l}\text { Richness of Learning } \\
\text { Opportunities and Resources }\end{array}$ & $\begin{array}{l}\text { Library, research resources, laboratories, centers, research } \\
\text { facilities, special study areas, academic support units }\end{array}$ \\
\hline $\begin{array}{l}\text { Personal Development and Career } \\
\text { Support }\end{array}$ & $\begin{array}{l}\text { Certificates, career, and orientation, personal competence } \\
\text { enhancement activities, courses for students, employment } \\
\text { prospect and support }\end{array}$ \\
\hline
\end{tabular}

Source: Karadağ \& Yücel, 2017

\section{METHOD}

\subsection{Dataset and Variables}

The dataset is collected from TUSS-2020 Report, the latest published results, consisting of a total of 192 state and foundation universities. Usable data are collected from 39,386 students (female: $\% 52.1$, male: \%47.9).

The factors of the Student Satisfaction Scale are separated into dependent and independent groups by conducting the DEMATEL technique. The distribution of variables by groups is given in Table 2. After determining the groups and their variables, Canonical Analysis is carried out to find out the relationship between these groups. 
Table 2. Independent and Dependent Variables

Independent Variables

$\mathrm{X}_{1}$ : Campus and the Fulfilment of Campus Life

$\mathrm{X}_{2}$ : Academic Support and Interest

$\mathrm{X}_{3}$ : Richness of Learning Opportunities and

Resources

$\mathrm{X}_{4}$ : Personal Development and Career Support
Dependent Variables

$\mathrm{Y}_{1}$ : Satisfaction with the Learning Experience

$\mathrm{Y}_{2}$ : Satisfaction with the Institution's

Management and Operation

\subsection{Model Building}

\subsubsection{DEMATEL Method}

Decision making trial and evaluation laboratory (DEMATEL), which was proposed by Gabus and Fontela (1972), is a multiple criteria decision making (MCDM) method that aims to reveal and analyze the causality relationship between complex factors. This method differs from other MCDM methods due to its ability to distinguish between variables affecting and affected. In this context, the method transforms the relationship between the causes and effects of the factors into a comprehendible structural model (Wu \& Lee, 2007).

The steps of DEMATEL are listed below (Gabus \& Fontela, 1972; Ayçin, 2020):

Step 1: Obtaining The Direct-Relation Matrix: The direct relation matrix is a matrix obtained by pairwise comparisons in terms of influences and directions between criteria. There are a total of five effect degrees: 0, 1, 2, 3, and 4. These degrees represent "no influence", "very low influence", "low influence", "high influence", and "very high influence", respectively. The representation of the matrix is as follows:

$$
\mathrm{D}=\left[\begin{array}{ccc}
\mathrm{d}_{11} & \mathrm{~d}_{1 \mathrm{j}} & \mathrm{d}_{1 \mathrm{n}} \\
\vdots & \vdots & \vdots \\
\mathrm{d}_{\mathrm{i} 1} & \mathrm{~d}_{\mathrm{ij}} & \mathrm{d}_{\mathrm{in}} \\
\vdots & \vdots & \vdots \\
\mathrm{d}_{\mathrm{n} 1} & \mathrm{~d}_{\mathrm{nj}} & \mathrm{d}_{\mathrm{nn}}
\end{array}\right]
$$

Each element in the matrix shows the degree of influence of a variable on any other variable. For example, d21 indicates the degree of influence of "Variable 2" on "Variable 1". Since a variable does not affect itself, the diagonal elements of the matrix will be zero.

Step 2: Obtaining The Normalized Direct-Relation Matrix: In this step, the values in each row and each column of the matrix are added up one by one. The matrix is normalized by dividing each element of the matrix by the maximum of these values. The following equations are used in the normalization process:

$$
\begin{aligned}
& X=s . D \\
& S=\min \left[\frac{1}{{ }_{i}^{\max } \sum_{j=1}^{n}\left|d_{\mathrm{ij}}\right|}\right],\left[\frac{1}{{ }_{j}^{\max } \sum_{\mathrm{i}=1}^{\mathrm{n}}||_{\mathrm{ij}} \mid}\right]
\end{aligned}
$$


Step 3: Obtaining The Total-Relation Matrix: At this stage, the direct relationship matrix normalized in the previous stage is transformed into the total effect matrix shown in Equation (5) by using the formula in Equation (4).

$$
\begin{aligned}
T & =X+X^{2}+\cdots+X^{h}=X(I-X)^{-1} \\
T & =\left[\begin{array}{ccc}
t_{11} & t_{1 j} & t_{1 n} \\
\vdots & \vdots & \vdots \\
t_{i 1} & t_{i j} & t_{i n} \\
\vdots & \vdots & \vdots \\
t_{n 1} & t_{n j} & t_{n n}
\end{array}\right]
\end{aligned}
$$

Step 4: Determining the Affecting and Affected Variables: $d_{i}$ for each row and $r_{j}$ for each column are computed using the equations below. Then $\left(d_{i}+r_{j}\right)$ and $\left(d_{i}-r_{j}\right)$ values are calculated.

$$
\begin{array}{ll}
\mathrm{d}_{\mathrm{i}}=\sum_{\mathrm{j}=1}^{\mathrm{n}} \mathrm{t}_{\mathrm{ij}} & \mathrm{D}=\left[\begin{array}{c}
\mathrm{d}_{1} \\
\vdots \\
\mathrm{d}_{\mathrm{i}} \\
\vdots \\
\mathrm{d}_{\mathrm{n}}
\end{array}\right]_{\mathrm{n \times 1}} \\
\mathrm{r}_{\mathrm{j}}=\sum_{\mathrm{i}=1}^{\mathrm{n}} \mathrm{t}_{\mathrm{ij}} & \mathrm{R}=\left[\begin{array}{lllll}
\mathrm{r}_{1} & \cdots & \mathrm{r}_{j} & \cdots & \\
& \mathrm{r}_{\mathrm{n}}
\end{array}\right]_{1 \times n}
\end{array}
$$

To determine the affecting and affected variables, the decision is made according to the following situations:

- The variable with a high $d_{j}+r_{j}$ value is more related to other variables and the lower $d_{j}+r_{j}$ value is less related to the other variables.

- The variable with a positive $d_{j}-r_{j}$ value is in the affecting group and the variable with a negative $d_{j}-r_{j}$ value is in the affected group.

\subsubsection{Canonical Correlation Analysis}

Canonical Correlation Analysis (CCA), which was proposed by Hotelling (1936), is a multivariate statistical technique. Hotelling (1936) investigated the relationship between reading ability $(\mathrm{X})$ and arithmetic ability $(\mathrm{Y})$ by using an example of four variables (reading speed: $\mathrm{X}_{1}$, reading power: $\mathrm{X}_{2}$, arithmetic speed: $\mathrm{Y}_{1}$, and arithmetic power: $\mathrm{Y}_{2}$ ) from a sample of 140 seventh-grade school children.

The CCA aims to identify and measure the relationships between two groups of variables (Johnson \& Wichern, 2007). Each group has at least two variables, since if one group has only one variable then a t-test or regression analysis can be applied. Theoretically, CCA can be applied to more than two groups, but in general, CCA is conducted to investigate the two groups' relationships (Thompson, 2000).

The correlation calculated by CCA is based on a linear combination of one group's variables and the other group's variables. In the analysis, the pair of linear combinations that have the largest correlation are determined. Afterwards, all pairs uncorrelated to the selected pair are determined and the same process (specifying the pair of linear combinations that have the largest correlation) is repeated between them. Canonical variables are the pairs of linear combinations. Correlations of canonical variables are called canonical correlations (Johnson \& Wichern, 2007). 
Mathematically, it can be represented as follows (Tacq, 1997):

$$
\begin{aligned}
& \mathrm{X}^{*}=\mathrm{a}_{1} \mathrm{X}_{1}+\mathrm{a}_{2} \mathrm{X}_{2}+\cdots+\mathrm{a}_{\mathrm{p}} \mathrm{X}_{\mathrm{p}} \\
& \mathrm{Y}^{*}=\mathrm{b}_{1} \mathrm{Y}_{1}+\mathrm{b}_{2} \mathrm{Y}_{2}+\cdots+\mathrm{b}_{\mathrm{q}} \mathrm{Y}_{\mathrm{q}}
\end{aligned}
$$

Where, $X^{*}$ is a linear combination equation of one set (X; containing $\mathrm{p}$ variables), $Y^{*}$ is a linear combination equation of the other set (Y; containing $\mathrm{p}$ variables), and $r_{c}$ is the correlation between them. In CCA, $a_{i}$ and $b_{i}$ values are estimated such that the correlation between $X^{*}$ and $Y^{*}\left(r_{c}\right)$ is maximized. The canonical variable pairs and the canonical correlation coefficient are calculated as the number of variables in the group, whichever of the $\mathrm{X}$ and $\mathrm{Y}$ groups has fewer variables $(\mathrm{s}=\mathrm{Min}(\mathrm{p}, \mathrm{q})$ ). Each of the obtained canonical variable pairs, $\left(X_{1}^{*}, Y_{1}^{*}\right),\left(X_{2}^{*}, Y_{2}^{*}\right), \ldots,\left(X_{S}^{*}, Y_{S}^{*}\right)$, represents an independent dimension in the relationship between two variable groups (Manly \& Alberto, 2016).

CCA lacks giving information about the explained variance between the $\mathrm{X}$ and $\mathrm{Y}$ sets. The square of the canonical correlation (eigenvalue) gives information about the common variance between canonical variables. Thus, the redundancy index is calculated to overcome this issue (Van Den Wollenberg, 1977). If the index is close to 1, it shows that the Y's variance (or X) being shared with the $\mathrm{X}$ (or Y) is significant (Mazuruse, 2014).

This technique is popularly used since in reality there are multiple causes and effects. Analyzing just one variable or set can not be enough to seek relational information. In addition to that, CCA is much more sensible than conducting univariate tests due to the inflation of experiment-wise (Type I) error rates (Thompson, 2000).

\section{RESULTS / FINDINGS}

\subsection{DEMATEL Results}

The DEMATEL method is applied to determine which of the six factors in the TUSS are affecting (independent) and which are affected (dependent) variables. With this aim, the following direct relation-matrix (Table 3.) is obtained by obtaining the opinions of an expert.

Table 3. The Direct Relation-Matrix

\begin{tabular}{ccccccc}
\hline & CL & AS & LO & PD & LE & IM \\
\hline $\mathbf{C L}$ & 0 & 2 & 2 & 2 & 4 & 4 \\
\hline $\mathbf{A S}$ & 0 & 0 & 3 & 1 & 4 & 3 \\
\hline $\mathbf{L O}$ & 0 & 1 & 0 & 1 & 4 & 4 \\
\hline $\mathbf{P D}$ & 0 & 0 & 0 & 0 & 3 & 2 \\
\hline $\mathbf{L E}$ & 0 & 0 & 0 & 0 & 0 & 2 \\
\hline $\mathbf{I M}$ & 2 & 0 & 0 & 0 & 0 & 0 \\
\hline
\end{tabular}

The variables are abbreviated as follows for an easy representation of the matrix:

- CL: Campus and the Fulfilment of Campus Life

- AS: Academic Support and Interest

- LO: Richness of Learning Opportunities and Resources 
- PD: Personal Development and Career Support

- LE: Satisfaction with Learning Experience

- IM: Satisfaction with the Institution's Management and Operation

After applying the steps of DEMATEL, the affecting and affected variables, in other words, independent and dependent variables are determined (Table 4.).

Table 4. Affecting and Affected Variables

\begin{tabular}{cccccc}
\hline & $\mathbf{D}_{\mathbf{i}}$ & $\mathbf{R}_{\mathbf{j}}$ & $\mathbf{D}_{\mathbf{i}}+\mathbf{R}_{\mathbf{j}}$ & $\mathbf{D}_{\mathbf{i}}-\mathbf{R}_{\mathbf{j}}$ & Effect Group \\
\hline $\mathbf{C L}$ & 1.3789 & 0.3314 & 1.7103 & 1.0475 & Affecting \\
\hline $\mathbf{A S}$ & 1.0501 & 0.2730 & 1.3231 & 0.7771 & Affecting \\
\hline $\mathbf{L O}$ & 0.8955 & 0.4321 & 1.3276 & 0.4634 & Affecting \\
\hline $\mathbf{P D}$ & 0.4108 & 0.3579 & 0.7686 & 0.0529 & Affecting \\
\hline $\mathbf{L E}$ & 0.1756 & 1.3480 & 1.5236 & -1.1724 & Affected \\
\hline $\mathbf{I M}$ & 0.3172 & 1.4857 & 1.8028 & -1.1685 & Affected \\
\hline
\end{tabular}

As can be seen in Table 4., the findings of the DEMATEL method show that four variables are affecting and two variables are affected variables (hereafter referred to as independent and dependent variables).

\subsection{Canonical Correlation Analysis Results}

SPSS (Version 25.0) is used to carry out Canonical Correlation Analysis. The proposed model for CCA is given in Figure 1.

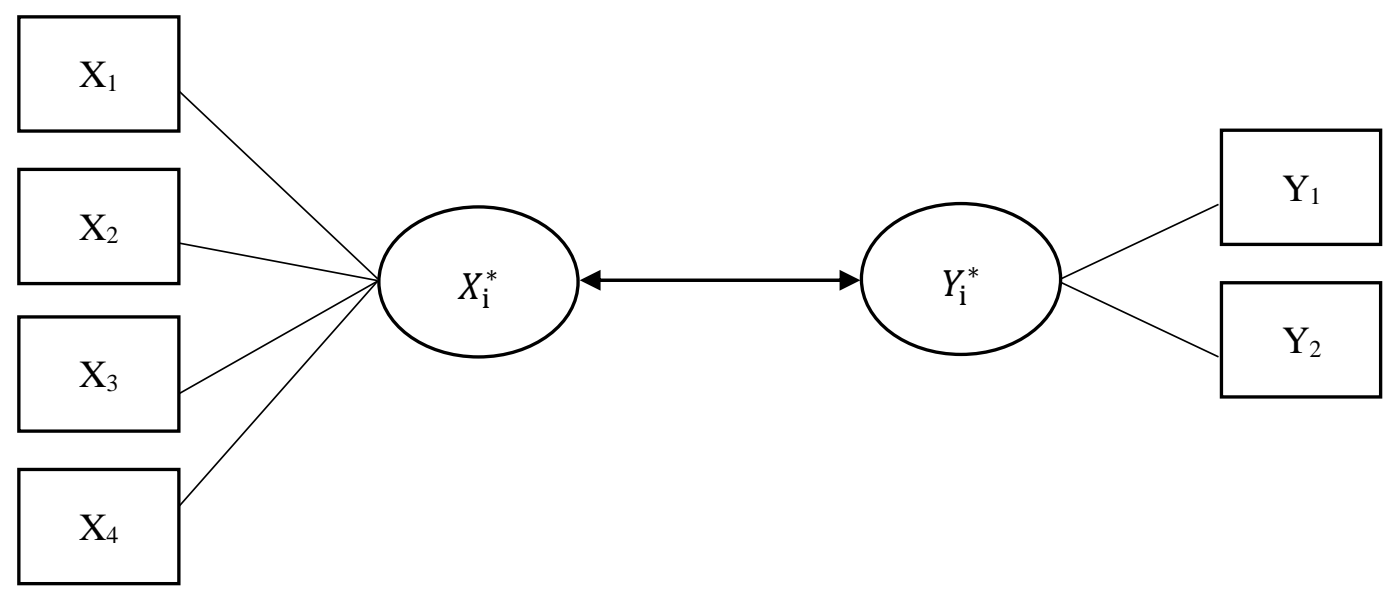

Figure 1. The Model for CCA

CCA is conducted based on the two dependent variables ( $\mathbf{Y}_{1}$ : Satisfaction with the Learning Experience, $\mathbf{Y}_{2}$ : Satisfaction with the Institution's Management and Operation) and the four independent variables $\left(\mathbf{X}_{\mathbf{1}}\right.$ : Campus and the Fulfilment of Campus Life, $\mathbf{X}_{\mathbf{2}}$ : Academic Support and Interest, $\mathbf{X}_{\mathbf{3}}$ : Richness of Learning Opportunities and Resources, $\mathbf{X}_{\mathbf{4}}$ : Personal Development and Career Support) to evaluate the relationship between these variable sets. The findings of CCA are interpreted based on 
canonical weights, canonical loadings, canonical cross-loadings, the proportion of explained variance, and redundancy index.

\subsubsection{Correlation Findings}

First of all, correlations between independent variables, correlations between dependent variables, and correlations between dependent and independent variables are given in Table 5. When the correlations between independent variables are examined, it is seen that the highest relationship is between $\mathrm{X}_{2}$ and $\mathrm{X}_{4}$ (\%90.56), "academic support and interest" and "personal development and career support". Also, it is observed that the relationships between variables $X_{1}$ and $X_{3}, X_{2}$, and $X_{3}$ and $X_{3}$ and $\mathrm{X}_{4}$ are also quite strong $(86.52 \%, 86.69 \%$, and $88.23 \%)$. The lowest correlation is between $\mathrm{X}_{1}$ and $\mathrm{X}_{4}$, namely "campus and the fulfilment of campus life", "personal development and career support" variables. According to the results of the dependent variables, the relationship between "satisfaction with learning experience" and "satisfaction with the institution's management and operation", is found to be $84.68 \%$. Therefore, it can be said that there is a strong relationship between them. The last correlation table shows that there are strong positive relationships between the $\mathrm{Y}_{1}$ variable (satisfaction with learning experience) and $X_{2}$ (academic support and interest), $X_{3}$ (richness of learning opportunities and resources), and $\mathrm{X}_{4}$ (personal development and career support), respectively $92.43 \%, 82.58 \%$, and 91.1\%. Finally, satisfaction with the institution's management and operation ( $\mathrm{Y}_{2}$ variable) has a strong relationship with academic support and interest (85.33\%) and personal development and career support $(82.80 \%)$.

Table 5. Correlations among the Variables

\begin{tabular}{|c|c|c|c|c|}
\hline \multicolumn{5}{|c|}{ Correlations Between Independent Variables } \\
\hline & $\mathbf{X}_{1}$ & $\mathbf{X}_{2}$ & $\mathbf{X}_{3}$ & $\mathbf{X}_{4}$ \\
\hline $\mathbf{X}_{1}$ & 1.0000 & 0.7725 & 0.8652 & 0.7534 \\
\hline $\mathbf{X}_{2}$ & 0.7725 & 1.0000 & 0.8669 & 0.9056 \\
\hline $\mathbf{X}_{3}$ & 0.8652 & 0.8669 & 1.0000 & 0.8823 \\
\hline $\mathbf{X}_{4}$ & 0.7534 & 0.9056 & 0.8823 & 1.0000 \\
\hline \multicolumn{5}{|c|}{ Correlations Between Dependent Variables } \\
\hline & & $\mathbf{Y}_{1}$ & $\mathbf{Y}_{2}$ & \\
\hline & $\mathbf{Y}_{1}$ & 1.0000 & 0.8468 & \\
\hline & $\mathbf{Y}_{2}$ & 0.8468 & 1.0000 & \\
\hline \multicolumn{5}{|c|}{ Correlations Between Dependent and Independent Variables } \\
\hline & $\mathbf{X}_{1}$ & $\mathbf{X}_{2}$ & $\mathbf{X}_{3}$ & $\mathbf{X}_{4}$ \\
\hline $\mathbf{Y}_{1}$ & 0.7586 & 0.9243 & 0.8258 & 0.9110 \\
\hline $\mathbf{Y}_{2}$ & 0.6758 & 0.8533 & 0.7637 & 0.8280 \\
\hline
\end{tabular}




\subsubsection{Canonical Correlations and Test Results}

In this study, Wilks's Lambda $(\lambda)$ is conducted as it is the most common test to assess the model (Sherry \& Henson, 2005). There are two pairs of canonical variables in the study that provide two canonical correlation coefficients $(s=\min (4,2)=2$ ). To interpret the results of Bartlett's Wilks's Lambda Test results, the null hypothesis can be stated as follows:

$$
\mathbf{H}_{\mathbf{0}}: \rho_{1}=\rho_{2}=0
$$

The alternative hypothesis states that at least one of the canonical correlations is non-zero. As shown in Table 6., only the first canonical correlation coefficient is found to be significant $(p=0.00$ $<0.05)$. Therefore, only the results for the first canonical variable are interpreted.

Table 6. Canonical Correlations and Test Results

\begin{tabular}{|c|c|c|c|c|c|c|}
\hline & $\begin{array}{c}\text { Canonical } \\
\text { Correlation } \\
\text { Coefficient (r) }\end{array}$ & $\begin{array}{c}\text { Eigenvalue } \\
\left(\mathbf{r}^{2}\right)\end{array}$ & $\begin{array}{c}\text { Wilk's } \\
\text { Lambda }\end{array}$ & Chi-SQ & DF & Sig. \\
\hline 1 & 0.951 & 0.9044 & 0.094 & 443.463 & 8.000 & 0.000 \\
\hline 2 & 0.123 & 0.0151 & 0.985 & 2.842 & 3.000 & 0.417 \\
\hline
\end{tabular}

The first canonical function shows the relationship between the first dependent canonical variable and the first independent canonical variable, and this relationship gives the maximum correlation coefficient (0.951). The square of the canonical correlation coefficient is equal to the eigenvalue. The eigenvalue is the proportion of explained variance by the independent variable in the dependent variable and the proportion of explained variance by the dependent variable in the independent variable. It is shown that $90.44 \%$ of the variance between the two sets of variables is explained by the first canonical correlation and $1.51 \%$ by the second canonical correlation.

\subsubsection{Canonical Weights}

Due to its meaningful results, standardized canonical weights are interpreted. The first independent canonical variable and first dependent canonical variable are the categorical variables that make the relationship between independent variables and dependent variables the highest. The canonical correlation coefficient showing the degree of this relationship is 0.951 . 
Table 7. Standardized Canonical Coefficients of the Independent \& Dependent Variable Set

Standardized Canonical Coefficients for the Independent Set

\begin{tabular}{rcccc}
\hline & $\mathbf{X}_{\mathbf{1}}$ & $\mathbf{X}_{\mathbf{2}}$ & $\mathbf{X}_{\mathbf{3}}$ & $\mathbf{X}_{\mathbf{4}}$ \\
\hline $\mathbf{X}_{\mathbf{1}}^{*}$ & -0.126 & -0.607 & 0.180 & -0.479 \\
\hline $\mathbf{X}_{\mathbf{2}}^{*}$ & -1.696 & 1.151 & 2.075 & -1.654 \\
\hline
\end{tabular}

Standardized Canonical Coefficients for the Dependent Set

\begin{tabular}{ccc}
\hline & $\mathbf{Y}_{1}^{*}$ & $\mathbf{Y}_{\mathbf{2}}^{*}$ \\
\hline $\mathbf{Y}_{\mathbf{1}}$ & -0.796 & -1.704 \\
\hline $\mathbf{Y}_{\mathbf{2}}$ & -0.232 & 1.866 \\
\hline
\end{tabular}

The first canonical variable pair is obtained with the following equations:

$$
\begin{aligned}
& \mathrm{X}_{1}^{*}=-0.216 \mathrm{X}_{1}-0.607 \mathrm{X}_{2}+0.18 \mathrm{X}_{3}-0.479 \mathrm{X}_{4} \\
& \mathrm{Y}_{1}^{*}=-0.796 \mathrm{Y}_{1}-0.232 \mathrm{Y}_{2}
\end{aligned}
$$

Taking into account the absolute sizes, it is obtained that the order of contribution of independent variables to the first dependent canonical variable is $\mathrm{X}_{2} \mathrm{X}_{4}, \mathrm{X}_{3}$, and $\mathrm{X}_{1}$.

Therefore, while the independent variable with the highest contribution is academic support and interest; personal development and career support ranked second, richness of learning opportunities and resources ranked third, and campus and the fulfilment of campus life ranked fourth.

\subsubsection{Canonical Loadings}

Canonical loadings give the simple linear correlation coefficient between the original variable and its canonical variable. Therefore, it enables the determination of the original variables that contribute the most to canonical variables and canonical correlation coefficient. The canonical loads for the variable sets are given in Table 8 .

Table 8. Canonical Loadings of the Independent \& Dependent Variable Set

\section{Canonical Loadings for the Independent Variable Set}

\begin{tabular}{ccccc}
\hline & $\mathbf{X}_{\mathbf{1}}$ & $\mathbf{X}_{\mathbf{2}}$ & $\mathbf{X}_{\mathbf{3}}$ & $\mathbf{X}_{\mathbf{4}}$ \\
\hline $\mathbf{X}_{\mathbf{1}}^{*}$ & -0.800 & -0.982 & -0.877 & -0.964 \\
\hline $\mathbf{X}_{\mathbf{2}}^{*}$ & -0.257 & 0.143 & 0.147 & -0.058
\end{tabular}

Canonical Loadings for the Dependent Variable Set

\begin{tabular}{lll}
\hline & $\mathbf{Y}_{\mathbf{1}}^{*}$ & $\mathbf{Y}_{2}^{*}$ \\
\hline $\mathbf{Y}_{\mathbf{1}}$ & -.992 & -.124 \\
\hline $\mathbf{Y}_{\mathbf{2}}$ & -.906 & .423 \\
\hline
\end{tabular}


The order of contribution of original variables in the independent set to the first independent canonical variable is $\mathrm{X}_{2} \mathrm{X}_{4}, \mathrm{X}_{3}$, and $\mathrm{X}_{1}$. Therefore, it is seen that academic support and interest provide the highest contribution, while campus and the fulfilment of campus life provide the lowest contribution. The original variables that contribute the most to the first dependent canonical variable are $Y_{1}$ and $Y_{2}$, respectively. Therefore, it is seen that the variable that makes the most contribution is satisfaction with the learning experience.

\subsubsection{Canonical Cross-Loadings}

Canonical cross-loadings show the simple correlation coefficient between original independent variables and dependent canonical variables, and original dependent variables and independent canonical variables.

Table 9. Canonical Cross-Loadings of the Independent \& Dependent Variable Set

Cross-Loadings for the Independent Variable Set

\begin{tabular}{ccccc}
\hline & $\mathbf{X}_{\mathbf{1}}$ & $\mathbf{X}_{\mathbf{2}}$ & $\mathbf{X}_{\mathbf{3}}$ & $\mathbf{X}_{\mathbf{4}}$ \\
\hline $\mathbf{Y}_{\mathbf{1}}^{*}$ & -0.761 & -0.934 & -0.834 & -0.917 \\
\hline $\mathbf{Y}_{\mathbf{2}}^{*}$ & -0.031 & 0.017 & 0.018 & -0.007 \\
\hline
\end{tabular}

Cross-Loadings for the Dependent Variable Set

\begin{tabular}{ccc}
\hline & $\mathbf{X}_{\mathbf{1}}^{*}$ & $\mathbf{X}_{\mathbf{2}}^{*}$ \\
\hline $\mathbf{Y}_{\mathbf{1}}$ & -0.944 & -0.015 \\
\hline $\mathbf{Y}_{2}$ & -0.862 & 0.052 \\
\hline
\end{tabular}

As given in Table 9., independent original variables contributing to the first dependent canonical variable are $\mathrm{X}_{2} \mathrm{X}_{4}, \mathrm{X}_{3}$, and $\mathrm{X}_{1}$, respectively. The most contributing independent variable is academic support and interest. The dependent variables contributing to the first independent canonical variable are $\mathrm{Y}_{1}$ and $\mathrm{Y}_{2}$, respectively. Therefore, satisfaction with the learning experience gives the most contribution.

\subsubsection{The Proportion of Explained Variance}

The explained variance ratio shows the part that the canonical variables in the dependent or independent set explain in the variables in the related set. It is calculated by taking the average of the squares of the canonical loads of each canonical variable in the related set. Table 10. shows the proportion of explained variance for the independent and dependent variable sets. 
Table 10. The Proportion of Explained Variance of the Independent \& Dependent Variable Set

\begin{tabular}{cccc}
\hline The Independent Variable Set & \multicolumn{2}{c}{ The Dependent Variable Set } \\
\hline $\mathbf{X}_{\mathbf{1}}^{*}$ & 0.826 & $\mathbf{Y}_{\mathbf{1}}^{*}$ & 0.903 \\
\hline $\mathbf{X}_{\mathbf{2}}^{*}$ & 0.028 & $\mathbf{Y}_{\mathbf{2}}^{*}$ & 0.097 \\
\hline Total & 0.854 & Total & 1.000 \\
\hline
\end{tabular}

Since the second canonical variable is not significant, it is obtained that the sum of only the variance explained by the first canonical variable in the independent set is 0.826 . The sum of the proportion of explained variance for the dependent or independent variable set is 1 if the number of variables in that set is equal to the number of canonical variables, which is the case for the dependent variable set.

\subsubsection{Redundancy Index}

The part of the variability in the dependent (or the independent) variable set explained by the independent (or the dependent) variable set is interpreted with the Redundancy Index.

Table 11. Redundancy Index of the Independent \& Dependent Variable Set

\begin{tabular}{cccc}
\hline \multicolumn{2}{c}{ The Independent Variable Set } & \multicolumn{2}{c}{ The Dependent Variable Set } \\
\hline $\mathbf{X}_{\mathbf{1}}^{*}$ & 0.747 & $\mathbf{Y}_{\mathbf{1}}^{*}$ & 0.817 \\
\hline $\mathbf{X}_{\mathbf{2}}^{*}$ & 0.000 & $\mathbf{Y}_{\mathbf{2}}^{*}$ & 0.001 \\
\hline Total & 0.747 & Total & 0.818 \\
\hline
\end{tabular}

$81.8 \%$ of the total variability in the dependent variables can be explained by independent variables. The proportion of the first independent canonical variable to explain the change in the dependent variables is $81.7 \%$. Also, the proportion of the first dependent canonical variable explaining the change in independent variables is $74.7 \%$.

\section{DISCUSSION AND CONCLUSION}

Numerous studies have been conducted to measure student satisfaction in higher education. In this study, variables obtained from TUSS-2020 Report are investigated to comprehend the relationship between students' satisfaction criteria by a hybrid model of DEMATEL and Canonical Correlation Analysis. The findings suggest that "satisfaction with the learning experience" and "satisfaction with the institution's management and operation" are affected by "campus and the fulfilment of campus life", "academic support and interest", "richness of learning opportunities and resources", and "personal development and career support".

"Academic support and interest" and "personal development and career support" come to the fore as the variables that most affect the overall satisfaction ("satisfaction with the learning experience" and "satisfaction with the institution's management and operation"), whereas "campus and the fulfilment of campus life" give the lowest contribution. These results are supported by the findings of Douglas et al. (2006) and Butt \& Rehman (2010) since the facilities are found to be the least important 
aspect that affects student satisfaction in these studies. Similarly, in Elliott (2002), Wiers-Jenssen et al. (2002), Tütüncü \& İpekgil Doğan (2003), and Kärnä \& Julin (2015) studies, academic quality and teaching aspects have the greatest impacts on overall satisfaction.

The findings of the study show the cause and effect relationships between the student satisfaction criteria that may suggest different sights. First, "satisfaction with the learning experience" and "satisfaction with the institution's management and operation" are affected by "academic support and interest" and "personal development and career support" at the most. Based on this finding, to increase the overall satisfaction towards the institution, dwelling on meeting students' academic and career expectations can be suggested. It may have a direct effect to increase the students' satisfaction. Another important implication of the findings is that "satisfaction with the learning experience" has an important effect on campus life, academic support, learning opportunities, and personal development. This finding is reasonable since it is directly related to the teaching approaches and the quality of the courses \& assessments. As a final point, to the best of our knowledge, no research has been done about TUSS and this is the first study that examines student satisfaction aspects' relationships in a different perspective with a hybrid model consisting of multiple criteria decision making (MCDM) technique (DEMATEL) and multivariate statistical technique (Canonical Correlation Analysis).

The current study has some limitations. First, this study is based on a report conducted in Turkey. New studies could be carried out based on surveys applied in different countries or globally. Second, the current study does not evaluate the rankings of the universities. Cluster analysis may be applied to investigate the separation of universities. Additionally, future studies may take several years of data into account and compare findings over years.

\section{REFERENCES}

Ayçin, E. (2020). Çok Kriterli Karar Verme Bilgisayar Uygulamalı Çözümler. 2. Baskı, Ankara: Nobel Yayın.

Barnes, B. J. \& Randall, J. (2012). "Doctoral Student Satisfaction: An Examination of Disciplinary, Enrollment and Institutional Differences". Research in Higher Education, 53(1), 47-75.

Bolliger, D. U. (2004). "Key Factors for Determining Student Satisfaction in Online Courses”. International Journal on Elearning, 3(1), 61-67.

Butt, B. Z. \& Ur Rehman, K. (2010). “A Study Examining the Students Satisfaction in Higher Education”. Procedia-Social and Behavioral Sciences, 2(2), 5446-5450.

Dericks, G., Thompson, E., Roberts, M., \& Phua, F. (2019). "Determinants of PhD Student Satisfaction: The Roles of Supervisor, Department and Peer Qualities”. Assessment \& Evaluation in Higher Education, 44(7), 1053-1068.

Douglas, J., Douglas, A. and Barnes, B. (2006). "Measuring Student Satisfaction at a UK University". Quality Assurance in Education, 14(3), 251-267.

Elliott, K.M. (2002). “Key Determinants of Student Satisfaction”. Journal of College Student Retention: Research, Theory \& Practice, 4(3), 271-279.

Elliott, K. M. \& Shin, D. (2002). "Student Satisfaction: An Alternative Approach to Assessing This Important Concept". Journal of Higher Education Policy and Management, 24(2), 197-209.

Gabus, A. \& Fontela, E. (1972). "World Problems, An Invitation to Further Thought within the Framework of DEMATEL". Battelle Geneva Research Centre, Geneva, Switzerland. 
Gibson, A. (2010). "Measuring Business Student Satisfaction: A Review and Summary of the Major Predictors". Journal of Higher Education Policy and Management, 32(3), 251-259.

González-Rogado, A. B., Rodríguez-Conde, M. J., Olmos-Migueláñez, S., Borham, M., \& García-Peñalvo, F. J. (2014). “Key Factors for Determining Student Satisfaction in Engineering: A Regression Study”. International Journal of Engineering Education (IJEE), 30(3), 576-584.

Grebennikov, L. \& Shah, M. (2013). "Monitoring Trends in Student Satisfaction”. Tertiary Education and Management, 19(4), 301-322.

Green, H. J., Hood, M., \& Neumann, D. L. (2015). "Predictors of Student Satisfaction with University Psychology Courses: A Review”. Psychology Learning \& Teaching, 14(2), 131-146.

Hanssen, T. E. S., \& Solvoll, G. (2015). "The Importance of University Facilities for Student Satisfaction at a Norwegian University”. Facilities, 33(13/14), 744-759.

Harvey, L. (1995). “Student Satisfaction”. New Review of Academic Librarianship, 1(1), 161-173.

Hotelling, H. (1936). "Relations Between Two Sets of Variables”. Biometrika, 28(3-4), 321-377.

Johnson, R. A., \& Wichern, D. W. (2007). Applied Multivariate Statistical Analysis. 6th Ed., Upper Saddle River, NJ: Pearson Prentice Hall.

Karemera, D., Reuben, L. J., \& Sillah, M. R. (2003). "The Effects of Academic Environment and Background Characteristics on Student Satisfaction and Performance: The Case of South Carolina State University's School of Business”. College Student Journal, 37(2), 298-309.

Karadağ, E. \& Yücel, C. (2017). “Türkiye Üniversite Memnuniyet Araştırmas1 [TÜMA-2017]: Rapor Özeti”. Yükseköğretim Dergisi, 7(2), 132-144.

Karadağ, E. \& Yücel, C. (2020). Türkiye Üniversite Memnuniyet Araştırması 2020. Üniar Yayınları.

Kärnä, S. \& Julin, P. (2015). “A Framework for Measuring Student and Staff Satisfaction with University Campus Facilities”. Quality Assurance in Education, 23(1), 47-66.

Koilias, C. (2005). "Evaluating Students' Satisfaction: The Case of Informatics Department of TEI Athens". Operational Research, 5(2), 363-381.

Letcher, D. W. \& Neves, J. S. (2010). "Determinants of Undergraduate Business Student Satisfaction”. Research in Higher Education Journal, 6, 1-26.

Manly, B. F. \& Alberto, J. A. N. (2016). Multivariate Statistical Methods: A Primer. Chapman and Hall/CRC.

Mazuruse, P. (2014). “Canonical Correlation Analysis”. Journal of Financial Economic Policy, 6(2), 179-196.

Naralan, A. \& Kaleli, S.S. (2012). "Üniversite Öğrencilerinin Üniversiteden Beklentileri ve Bölüm Memnuniyeti Araştırması: Atatürk Üniversitesi Örneği”. Organizasyon ve Yönetim Bilimleri Dergisi, 4(1), 1-11.

Sherry A. \& Henson R. K. (2005). "Conducting and Interpreting Canonical Correlation Analysis in Personality Research: A User-Friendly Primer”. Journal of Personality Assessment, 84(1), 37-48.

Solinas, G., Masia, M. D., Maida, G., \& Muresu, E. (2012). "What Really Affects Student Satisfaction? An Assessment of Quality Through a University-Wide Student Survey". Creative education, 3(1), 37-40.

Tacq, J. (1997). Multivariate Analysis Techniques in Social Science Research: From Problem to Analysis. Sage Publications.

Tayyar, N. \& Dilşeker, F. (2012). "Devlet ve Vakıf Üniversitelerinde Hizmet Kalitesi ve İmajın Öğrenci Memnuniyetine Etkisi”. Muğla Üniversitesi Sosyal Bilimler Enstitüsü Dergisi, 28, 184-203.

Thompson, B. (2000). Canonical Correlation Analysis. In L. Grimm \& P. Yarnold (Eds.), Reading and Understanding More Multivariate Statistics. Washington, DC: American Psychological Association, 285-316.

Tuan, N. M. (2012). "Effects of Service Quality and Price Fairness on Student Satisfaction”. International Journal of Business and Social Science, 3(19), 132-150.

Tütüncü, Ö. \& İpekgil Doğan, Ö. (2003). "Müşteri Tatmini Kapsamında Öğrenci Memnuniyetinin Ölçülmesi ve Dokuz Eylül Üniversitesi, Sosyal Bilimler Enstitüsü Uygulaması”. Dokuz Eylül Üniversitesi Sosyal Bilimler Enstitüsü Dergisi, 5(4), 130-151. 
Umbach, P. D., \& Porter, S. R. (2002). "How Do Academic Departments Impact Student Satisfaction? Understanding the Contextual Effects of Departments”. Research in Higher Education, 43(2), 209-234.

Uniar. (2021, January). Turkey University Satisfaction Survey. https://www.uniar.net/tuma

Van Den Wollenberg, A. L. (1977). "Redundancy Analysis an Alternative for Canonical Correlation Analysis". Psychometrika, 42(2), 207-219.

Weerasinghe, I. M. S. \& Fernando, R. L. S. (2018). "University Facilities and Student Satisfaction in Sri Lanka”. International Journal of Educational Management, 32(5), 866-880.

Wiers-Jenssen, J., Stensaker, B. \& GrØgaard, J.B. (2002). "Student Satisfaction: Towards an Empirical Deconstruction of the Concept". Quality in Higher Education, 8(2), 183-195.

Williams, J. \& Cappuccini-Ansfield, G. (2007). "Fitness for Purpose? National and Institutional Approaches to Publicising the Student Voice”. Quality in Higher Education, 13(2), 159-172.

Wu, W.W. \& Lee, Y.T. (2007). "Developing Global Managers' Competencies Using the Fuzzy DEMATEL Method”. Expert Systems with Applications, 32, 499-507.

Yang, Z., Becerik-Gerber, B., \& Mino, L. (2013). “A Study on Student Perceptions of Higher Education Classrooms: Impact of Classroom Attributes on Student Satisfaction and Performance". Building and Environment, 70, 171-188.

Zineldin, M., Akdag, H. C., \& Vasicheva, V. (2011). “Assessing Quality in Higher Education: New Criteria for Evaluating Students' Satisfaction”. Quality in Higher Education, 17(2), 231-243. 